\title{
Pengaruh Profesionalisme Auditor, Komitmen Organisasi dan Etika Profesi Pada Kinerja Auditor KAP Provinsi Bali
}

\author{
A.A Sayu Gita Wulandari ${ }^{1}$ \\ I Dewa Gde Dharma Suputra ${ }^{2}$
}

\author{
${ }^{1}$ Fakultas Ekonomi dan Bisnis Universitas Udayana (Unud), Bali, Indonesia \\ e-mail: sayugitawulandari@gmail.com/Telp : 087861751692 \\ ${ }^{2}$ Fakultas Ekonomi dan Bisnis Universitas Udayana (Unud), Bali, Indonesia
}

\begin{abstract}
ABSTRAK
Pada era globalisasi saat ini banyak sekali terjadi kasus-kasus hukum yang melibatkan manipulasi akuntansi. Profesi auditor telah menjadi sorotan masyarakat dalam beberapa tahun terakhir. Seorang auditor harus memiliki profesionalisme yang tinggi dalam menjalankan tugas-tugasnya. Hasil audit dari seorang auditor harus dapat dipertanggungjawabkan kepada pihak-pihak yang berkepentingan. Kinerja auditor merupakan hasil dari kerja auditor dalam melaksanakan penugasan pemeriksaan atas laporan keuangan suatu entitas dengan tujuan untuk menentukan kewajaran laporan keuangan. Tujuan penelitian ini adalah untuk mengetahui pengaruh profesionalisme auditor, komitmen organisasi, dan etika profesi pada kinerja auditor kantor akuntan publik di Provinsi Bali. Metode pengambilan sampel yang digunakan adalah metode purposive sampling, sedangkan metode pengumpulan data dilakukan dengan menggunakan kuesioner. Populasi dalam penelitian ini adalah seluruh auditor yang bekerja pada Kantor Akuntan Publik di Provinsi Bali. Kantor Akuntan Publik yang digunakan adalah Kantor Akuntan Publik yang terdaftar dalam Direktori yang diterbitkan oleh Institut Akuntan Publik Indonesia tahun 2017 yang beralokasi di Bali sejumlah 7 Kantor Akuntan Publik. Jumlah keseluruhan auditor dari 7 kantor tersebut terdapat 65 orang auditor. Banyaknya sampel penelitian yang digunakan adalah 36 responden. Teknik analisis data yang digunakan adalah teknik analisis regresi linear berganda. Hasil penelitian ini menunjukkan bahwa profesionalisme auditor, komitmen organisasi, dan etika profesi berpengaruh positif pada kinerja auditor.
\end{abstract}

Kata Kunci: Profesionalisme Auditor, Komitmen Organisasi dan Etika Profesi, Kinerja Auditor

\begin{abstract}
In the current era of globalization there are so many legal cases involving accounting manipulation. The auditor's profession has been a public spotlight in recent years. An auditor must have a high professionalism in carrying out his duties. Audit results from an auditor should be accountable to the parties concerned. The performance of the auditor is the result of the auditor's work in performing the assignment of examination of the financial statements of an entity with the aim of determining the reasonableness of the financial statements. The purpose of this study is to determine the influence of auditor professionalism, organizational commitment, and professional ethics on the performance of auditors public accounting firm in Bali Province. Sampling method used is purposive sampling method, while data collection method is done by using questioner. The population in this study are all auditors who work at Public Accounting Firm in Bali Province. Public Accounting Firm used is Public Accounting Firm which is registered in the Directory published by Indonesian Institute of Certified Public of 2017 which is located in Bali a number of 7 Public Accounting Firm. The total number of auditors from 7 offices is 65 auditors. The number of research samples used were 36 respondents. Data analysis technique used is multiple linear regression analysis technique. The results of this study
\end{abstract}


indicate that auditor professionalism, organizational commitment, and professional ethics have a positive effect on auditor performance.

Keywords: Auditor Professionalism, Organizational Commitment and Professional Ethics, Auditor Performance

\section{PENDAHULUAN}

Pada era globalisasi saat ini banyak sekali terjadi kasus-kasus hukum yang melibatkan manipulasi akuntansi. Profesi auditor telah menjadi sorotan masyarakat dalam beberapa tahun terakhir (Abu, 2013). Saat auditor menjalankan profesinya, auditor akan diatur sesuai kode etiknya yang dikenal dengan Kode Etik Akuntan. Dian (2011) menyatakan bahwa masyarakat mampu menilai auditor yang telah bekerja sesuai dengan standar-standar etika yang telah ditetapkan oleh profesinya melalui kode etik. Banyaknya kasus-kasus kelalaian atau kesalahan dalam mengaudit menuntut semua auditor harus memiliki sikap profesional, komitmen dalam organisasi dan mentaati etika profesi sebagai auditor. Meningkatnya berbagai kasus skandal akuntansi di dunia menyebabkan berbagai pihak berspekulasi bahwa manajemen telah melakukan kecurangan pada laporan keuangan (Skousen et al., 2008). Indonesia merupakan negara yang juga terkena wabah meluasnya kasus skandal kecurangan akuntansi.

Maraknya skandal kecurangan akuntansi di Indonesia dibuktikan dengan adanya likuidasi beberapa bank, diajukannya manajemen BUMN dan swasta ke pengadilan, kasus kejahatan perbankan, dan manipulasi pajak (Soselisa dan Mukhlasin, 2008). Salah satu contoh kasus terjadinya kecurangan laporan keuangan adalah kasus PT Kereta Api Indonesia. Dalam laporan kinerja keuangan tahunan yang diterbitkan pada tahun 2005, perusahaan mengumumkan keuntungan yang diperoleh sebesar Rp 6,90 milyar, namun setelah hasil audit 
diteliti dengan seksama perusahaanseharusnya dinyatakan menderita kerugian sebesar Rp 63,3 milyar. Kerugian ini terjadi karena PT Kereta Api Indonesia telah tiga tahun tidak dapat menagih pajak pihak ketiga. Dalam laporan keuangan tersebut pajak pihak ketiga dinyatakan sebagai pendapatan. Seharusnya berdasarkan standar akuntansi keuangan, pajak pihak ketiga tidak dapat dikelompokan dalam bentuk pendapatan atau aset. Dengan demikian, kekeliruan dalam pencatatan transaksi dan penyajiaan laporan keuangan telah terjadi pada kasus ini (Kompas, 2006). Kasus lainnya menimpa salah satu BUMN, yaitu PT Kimia Farma Tbk yang melakukan mark-up laporan keuangan, yaitu terjadinya penggelembungan laba bersih pada laporan keuangan tahun 2001 sebesar $\mathrm{Rp}$ 32,668 miliar. Perusahaan seharusnya menyajikan laba bersih sebesar Rp 99,594 miliar, namun perusahan menyajikan laba bersih sebesar Rp 132 miliar.

Kecurangan tersebut terungkap karena Bapepam menilai laba yang diperoleh perusahaan terlalu besar dan mengandung unsur rekayasa sehingga dilakukan audit ulang oleh Bapepam pada laporan keuangan Kimia Farma tahun 2001, hasil audit tersebut menyatakan bahwa perusahaan melakukan overstated penjualan dan persediaan yang mengakibatkan kesalahan penyajian laporan keuangan (Bapepam, 2002). Kasus kecurangan laporan keuangan tidak hanya terjadi di Indonesia, namun juga terjadi di luar negeri seperti pada perusahaan Enron, Worldcom, Global Crossing, dan Adelphia. Perusahaan tersebut merupakan contoh perusahan yang bangkrut akibat skandal kecurangan dalam bentuk pencurian aset, kejahatan komputer, korupsi, maupun kesalahan dalam penyajian laporan keuangan (Ilter, 2009). Kasus-kasus yang terjadi menuntut para 
auditor internal dan eksternal untuk dapat memahami kecurangan pada laporan keuangan. Kecurangan laporan keuangan merupakan masalah yang serius sehingga auditor sebagai pihak yang bertanggung jawab harus dapat mendeteksi aktivitas kecurangan sebelum akhirnya berkembang menjadi skandal akuntansi yang sangat merugikan.

Maka dari itu kinerja suatu Kantor Akuntan Publik yang berkualitas sangat ditentukan oleh kinerja para akuntannya. Profesi akuntan memiliki peran yang sangat penting dalam penyediaan informasi keuangan yang handal bagi pemerintah, kreditor, investor, debitur, pemegang saham, karyawan, juga bagi masyarakat dan pihak-pihak lain yang berkepentingan (Suseno, 2013 mensitir Boyton \& Kell, 2006:16). Dengan kata lain profesi akuntan sangat penting bagi para stakeholder dari suatu perusahaan. Mulyadi (2002:4) menyebutkan bahwa masyarakat mengharapkan penilaian yang bebas dan tidak memihak terhadap informasi yang disajikan oleh manajemen perusahaan dalam laporan keuangan dari audit yang dilakukan oleh akuntan publik. Danielle E. Warren dan Miguel Alzola (2008) menyebutkan bahwa secara umum tanggung jawab auditor bertindak secara obyektif. Profesi akuntan publik memiliki tanggung jawab untuk meningkatkan keandalan laporan keuangan perusahaan. Menurut Rahmawati (2011), profesi akuntan memiliki peran yang sangat penting bagi masyarakat yang berhubungan dengan tugas dan tanggung jawab auditor.

Seorang auditor independen dalam proses audit memberikan opini atas kewajaran laporan keuangan dengan judgment yang didasarkan pada kejadian masa lalu (Jamilah, dkk, 2007). Suatu perusahaan harus mampu menyajikan 
informasi yang memiliki relevansi, reliabilitas, daya uji, netralitas, dan disajikan dengan tepat. Agar dapat menjalankan perannya, auditor harus selalu menjaga mutu dan kualitas jasa yang diberikannya kepada kliennya. Seorang auditor harus memiliki profesionalisme yang tinggi dalam menjalankan tugas-tugasnya. Hasil audit dari seorang auditor harus dapat dipertanggungjawabkan kepada pihak-pihak yang berkepentingan dan baik buruknya pertanggungjawaban yang diberikan tergantung dari kinerja auditor.

Menurut Satwika (2015) mensitir Yanhari (2007), Kinerja auditor adalah kemampuan dari seorang auditor dalam menghasilkan temuan atau hasil dari kegiatan pemeriksaan atas pengelolaan dan tanggung jawab keuangan yang dilakukan dalam satu tim. Kinerja auditor merupakan suatu tindakan ataupun pelaksanaan tugas pemeriksaan yang telah diselesaikan oleh auditor dalam kurun waktu tertentu. Hanif (2013) mensitir Goldwasser (1993) menyatakan bahwa pencapaian kinerja auditor yang lebih baik harus sesuai dengan standar dan kurun waktu tertentu, yaitu: mutu menyelesaikan pekerjaan dengan bekerja berdasarkan pada seluruh kemampuan dan keterampilan serta pengetahuan yang dimiliki oleh auditor, hasil kerja yang dapat diselesaikan dengan target yang menjadi tanggung jawab pekerjaan auditor serta kemampuan untuk memanfaatkan sarana dan prasarana penunjang pekerjaan dan yang terakhir ketepatan waktu yang tersedia untuk menyelesaikan pekerjaan. Tentu dalam mencapai kinerja yang baik harus dilandasi dengan sikap professional dari seorang auditor tersebut. Profesionalisme adalah orang yang menjalani profesi sesuai dengan keahlian yang dimilikinya. Dalam hal ini, seorang yang memiliki profesionalisme dapat dipercaya dan 
diandalkan dalam melaksanakan pekerjaannya sehingga dapat berjalan lancar, baik dan mendatangkan hasil yang diharapkan (Hardjana, 2002). Profesionalisme seorang auditor dapat dilihat dengan adanya 5 konsep dasar profesionalisme yang diungkap oleh Hall (2007) yaitu: pengabdian pada profesi, kewajiban sosial, kemandirian, keyakinan terhadap peraturan profesi dan hubungan dengan rekan profesi. Tidak hanya itu dalam profesionalisme juga mensyaratkan 3 hal yaitu: mempunyai keahlian, melaksanakan tugas profesinya dengan menyesuaikan dengan standar umum profesi dan mematuhi etika profesi (Lekatompessy, 2003). Dengan begitu auditor akan auditor akan menjadi profesional.

Salah satu faktor individual yang mempengaruhi peningkatan kinerja adalah komitmen organisasi. Komitmen organisasi dapat diciptakan apabila anggota dari organisasi menyadari hak dan kewajibannya sebagai anggota tanpa melihat jabatan ataupun kedudukan masing-masing individu. Bariyima (2012) menyebutkan bahwa keberhasilan dan kinerja seseorang dalam suatu bidang pekerjaan sangat ditentukan oleh seberapa besar komitmen organisasi yang dimiliknya. Komitmen organisasi yang tinggi akan meningkatkan kinerja yang tinggi pula (Nouri dan Parker, 1998 mensitir Randall, 1990) Auditor yang memiliki komitmen terhadap organisasi akan menunjukkan sikap dan gaya kepemimpinan yang baik terhadap tempat ia bekerja, auditor akan memiliki rasa yang besar untuk membela organisasinya, berusaha meningkatkan prestasinya serta memiliki keyakinan yang pasti dalam hal mewujudkan tujuan organisasi (Arifah, 2008). Rendy (2012) menyebutkan bahwa secara signifikan variabel komitmen organisasi berpengaruh positif pada kinerja auditor. Hasil penelitian 
yang dilakuka oleh Mayer et al. (1989) dan Fernando et al. (2005) mengemukakan bahwa hubungan komitmen organisasi dengan kinerja adalah positif.

Etika profesi juga dapat mempengaruhi kinerja auditor. Menurut Ariyanto, dkk. (2010) dalam Putri, dkk (2013) etika profesi sangatlah dibutuhkan oleh masing-masing profesi untuk mendapatkan kepercayaan dari masyarakat, seperti profesi auditor. Setiap auditor harus mematuhi etika profesi mereka agar tidak menyimpangi aturan dalam menyelesaikan laporan keuangan kliennya. Dalam menjalankan profesinya akuntan publik juga dituntut untuk memiliki prinsip dan moral, serta perilaku etis yang sesuai dengan etika. Memahami peran perilaku etis seorang auditor dapat memiliki efek yang luas pada bagaimana bersikap terhadap klien mereka agar dapat bersikap sesuai dengan aturan akuntansi berlaku umum (Curtis et al., 2012). Mukadimah Kode Etik Ikatan Akuntan Indonesia (IAI) menyatakan prinsip etika profesi dalam kode etik Ikatan Akuntan Indonesia merupakan pengakuan profesi akantanggungjawabnya kepada publik, pemakai jasa akuntan, dan rekan (Abdul Halim, 2008:29). Prinsip ini memandu anggota dalam memenuhi tanggungjawab profesionalnya dalam melakukan pekerjaanya termasuk dalam membuat keputusan pemberian opini. Hal ini didukung dengan pendapat Gordon F. Woodbine dan Joanne Liu (2010) yaitu moralitas memainkan peran penting dalam proses pengambilan keputusan. Prinsip ini meminta komitmen untuk berperilaku terhormat, bahkan dengan pengorbanan keuntungan pribadi. Auditor Internal sudah memiliki kode etik tersendiri yang dibuat oleh Asosiasi Auditor Intern Pemerintah Indonesia (AAIPI) pada tahun 2014. Pada 
dasarnya kode etik tersebut mengambil konsep IIA. AAIPI menambah empat prinsip etika IIA dengan dua prinsip lagi yaitu akuntabel dan perilaku profesional. Prinsip-prinsip etika yang dirumuskan Ikatan Akuntan Publik Indonesia (IAPI) dan dianggap menjadi kode etik perilaku akuntan Indonesia adalah (1) tanggung jawab, (2) kepentingan masyarakat, (3) integritas, (4) obyektifitas dan independen, (5) kompetensi dan ketentuan profesi, (6) kerahasiaan, dan (7) perilaku profesional. Berdasarkan latar belakang dan hasil penelitian terdahulu yang telah diuraikan diatas, maka peneliti tertarik untuk mengambil judul: "Pengaruh Profesionalisme Auditor, Komitmen Organisasi dan Etika Profesi Pada Kinerja Auditor Kantor Akuntan Publik di Provinsi Bali”.

Auditing Menurut Mulyadi (2002) suatu proses sistematik untuk memperoleh dan mengevaluasi bukti secara objektif mengenai pernyataanpernyataan tentang kegiatan dan kejadian ekonomi dengan tujuan untuk menetapkan tingkat kesesuaian antara pernyataan-pernyataan tersebut dengan kriteria yang telah ditetapkan, serta penyampaian hasil-hasilnya kepada pemakai yang berkepentingan. Agoes (2004:3) mengatakan bahwa audit adalah suatu pemeriksaan yang dilakukan secara kritis dan sistematis, oleh pihak yang independen, terhadap laporan keuangan yang telah disusun oleh manajemen, beserta catatancatatan pembukuan dan bukti-bukti pendukungnya dengan tujuan untuk dapat memberikan pendapat mengenai kewajaran laporan keuangan tersebut.

Mangkunegara (2005:67) mengemukakan bahwa istilah kinerja berasal dari kata actual performance atau job performance (prestasi sesungguhnya yang 
dicapai seseorang atau prestasi kerja), yaitu hasil kerja secara kuantitas dan kualitas yang dicapai oleh seorang pegawai dalam melaksanakan tugasnya sesuai dengan tanggungjawab yang diberikan kepadanya. Gibson, et.al. (1996), menyatakan bahwa kinerja karyawan merupakan suatu ukuran yang dapat digunakan untuk menetapkan perbandingan hasil pelaksanaan tugas, tanggung jawab yang diberikan oleh organisasi pada periode tertentu dan relatif dapat digunakan untuk mengukur prestasi kerja atau kinerja organisasi.

Seseorang dikatakan profesional jika memenuhi tiga kriteria, yaitu mempunyai keahlian untuk melaksanakan tugas sesuai dengan bidangnya, melaksanakan suatu tugas atau profesi dengan menetapkan standar baku di bidang profesi yang bersangkutan dan menjalankan tugas profesinya dengan mematuhi etika profesi yang telah ditetapkan. Seorang auditor yang memiliki sikap profesionalisme dapat dipercaya dan diandalkan dalam melaksanakan pekerjaannya sehingga dapat berjalan lancar, baik dan mendatangkan hasil yang diharapkan (Hardjana, 2002).

Wati, dkk (2010) mensitir Robbins (2006) mengemukakan bahwa komitmen seorang karyawan pada suatu organisasi merupakan salah satu sikap yang mencerminkan perasaan suka maupun tidak suka seorang karyawan terhadap organisasi atau entitas tempat ia bekerja. Komitmen Organisasi didefinisikan sebagai kekuatan yang bersifat relative dari individu dalam mengidentifikasi keterlibatan dirinya ke dalam organisasi. (Kuang chi et, al, 2007 mensitir Porter, streers \& Mowday, 1982). Sementara Pamilih (2014) menyebutkan bahwa keberhasilan maupun kinerja seseorang dalam pekerjaan dapat ditentukan dari 
beberapa hal, yaitu tingkat kompetensi, profesionalisme dan juga komitmen terhadap bidang pekerjaan yang ditekuninya.

Menurut Rhara \& Dharma (2013) pemahaman tentang etika profesi akan mengarahkan sikap dan perilaku auditor dalam melaksanakan tugas, yaitu pengambilan keputusan yang benar dalam memberikan opini tentang wajar atau tidaknya suatu laporan keuangan, karena opini yang dikeluarkan oleh auditor akan digunakan para pengguna informasi keuangan. Kompetensi seorang auditor tidak hanya dilihat dari segi teknis tapi juga dari segi etika (Cathy dan Christine, 2011 mensitir Fortin and Martel, 1997). Etika profesi juga salah satu faktor yang mempengaruhi kualitas audit dan sangat diperlukan karena dalam kode etik mengatur perilaku akuntan publik menjalankan praktik.

Menurut Teori Keagenan manajemen sering melakukan tindakan yang dapat membuat laporannya terlihat baik agar kinerjanya juga baik. Dibutuhkan adanya pengujian untuk mengurangi kecurangan dan membuat laporan keuangan yang dibuat oleh pihak manajemen yang dapat dipercaya. Maka dari itu dibutuhkan pihak yang independen dalam melakukan pengujian tersebut yaitu auditor independen yang memiliki sikap professional atau bertanggungjawab terhadap tugas yang diberikan.

Menurut Bamber (2002), Cohen (2001), Pawitra (2011) yang menunjukkan bahwa profesionalisme berpengaruh positif terhadap kinerja auditor, yang dimana semakin tinggi tingkat keprofesionalismean auditor maka kinerja yang dihasilkan akan semakin memuaskan. Penelitian Friska (2012) mengatakan profesionalisme berarti bahwa auditor wajib melaksanakan tugas-tugasnya dengan kesungguhan 
dan kecermatan, sebagai seorang yang professional, auditor harus menghindari kelalaian dan ketidakjujuran. Jadi dapat disimpulkan apabila seorang auditor tidak memiliki atau telah kehilangan sikap profesionalismenya sebagai seorang auditor maka sudah dapat diyakini bahwa auditor tersebut tidak akan dapat menghasilkan hasil kinerja yang memuaskan dan dengan baik, maka dengan begitu kepercayaan dari masyarakat akan hilang begitu saja terhadap auditor tersebut. Oleh sebab itu sangatlah diperlukan sikap profesionalisme tersebut dalam menyelesaikan tugas tugas dengan tepat waktu. Berdasarkan uraian tersebut, maka dapat dirumuskan hipotesis sebagai berikut.

$\mathrm{H}_{1}$ : Profesionalisme auditor berpengaruh positif pada kinerja auditor

Theory of Planned Behavior menyatakan dengan salah satu determinannya yaitu terkait dengan sikap dasar seseorang (person in nature) disebut dengan attitude toward the behavior (sikap seorang terhadap perilaku). Contohnya adalah sikap seorang terhadap intuisi, terhadap orang lain, atau terhadap suatu objek. Dalam hal ini, sikap auditor terhadap lingkungan dimana ia bekerja (kantor), terhadap atasannya atau terhadap penjelasan dari kliennya, dan tentunya terhadap pemberian opininya atas laporan keuangan. Komitmen organisasi merupakan suatu hubungan antara anggota dengan organisasi. Komitmen organisasinal menunjukkan adanya suatu daya dari seseorang dalam mengidentifikasikan keterlibatannya dalam suatu bagian organisasi (Mowday, et. al., 2007).

Komitmen merupakan suatu konsistensi dari wujud keterikatan seseorang terhadap suatu hal. Adanya suatu komitmen dapat menjadi suatu dorongan bagi seseorang untuk bekerja lebih baik (Wibowo, 2009). Komitmen organisasi 
menurut Umam (2010:258) mensitir Meyer dan Allen (1991) sebagai suatu konstruk psikologi yang merupakan karakteristik hubungan anggota organisasi dengan organisasinya. Ketika seseorang menyukai organisasi tempat dimana dia bekerja maka dia akan memberikan kemampuan yang terbaik dan loyal untuk organisasinya tersebut, dengan kata lain anggota yang memiliki komitmen terhadap organisasinya maka dia akan lebih bertahan sebagai bagian dari organisasi dibandingkan anggota yang tidak memiliki komitmen terhadap organisasi.

Menurut Baihaqi (2010) komitmen organisasi berkaitan dengan sikap seseorang yang berhubungan dengan organisasi tempat mereka bergabung. Sikap ini berkaitan dengan persepsi tujuan organisasi dan keterlibatannya dalam melaksanakan kerja. Apabila komitmen seseorang tinggi maka kinerjanya akan menjadi lebih baik. Berdasarkan uraian tersebut maka dapat disimpulkan hipotesis sebagai berikut:

$\mathrm{H}_{2}$ : Komitmen organisasi berpengaruh positif pada kinerja auditor

Menurut Putri, dkk. (2013) mensitir Ariyanto, dkk. (2010) etika profesi sangatlah dibutuhkan oleh masing-masing profesi untuk mendapatkan kepercayaan dari masyarakat, seperti profesi auditor. Setiap auditor harus mematuhi etika profesi mereka agar tidak menyimpangi aturan dalam menyelesaikan laporan keuangan kliennya. Menurut Theory Planned of Behavior yang berkaitan dengan isu kontrol (issues of control) yang disebut dengan perceived behavioral control (persepsi mengenai kontrol perilaku). Faktor ini berkaitan dengan pengalaman masa lalu dan persepsi seseorang mengenai 
seberapa sulit untuk melakukan suatu perilaku tertentu (Achmat, 2010), oleh karena itu seorang auditor harus mempunyai panduan untuk berperilaku yang disebut etika profesi auditor. Berperilaku etis sesuai dengan etika profesi yang dianut menunjukkan bahwa seorang auditor tersebut dapat berkomitmen dengan baik dalam menjalankan tugasnya. Perilaku etis merupakan hal yang paling mendasar dalam melakukan suatu pekerjaan. Segala sesuatu yang berawal dari kesadaran dan ketulusan dalam bekerja maka hasilnya juga akan lebih baik.

Hasil dari Putri \& Suputra (2013) menunjukkan bahwa etika profesi berpengaruh positif terhadap kinerja auditor. Hasil ini sama dengan hasil penelitian dari Ariani (2009) yang menyatakan bahwa etika profesi berpengaruh positif terhadap kinerja auditor yang dimana apabila seorang auditor tidak memiliki atau mematuhi etika profesinya maka ia tidak akan dapat menghasilkan kinerja yang memuaskan bagi dirinya sendiri maupun kliennya. Oleh sebab itu seorang auditor haruslah memegang teguh etika profesinya sebagai seorang auditor agar tidak menyalah gunakan profesinya sendiri. Berdasarkan uraian tersebut maka dapat disimpulkan hipotesis sebagai berikut:

$\mathrm{H}_{3}$ : Etika profesi berpengaruh positif terhadap kinerja auditor

\section{METODE PENELITIAN}

Penelitian ini menggunakan pendekatan kuantitatif yang berbentuk asosiatif. Pendekatan kuantitatif dapat diartikan sebagai suatu metode penelitian yang digunakan untuk meneliti populasi atau sample tertentu yang bertujuan untuk menguji hipotesis tertentu yang telah ditetapkan (sugiyono, 2014:55). Menurut Rahayu (2004:17), penelitian asosiatif bertujuan untuk mengetahui hubungan 
antara dua variabel atau lebih. Penelitian ini membahas mengenai pengaruh profesionalisme auditor, komitmen organisasi dan etika profesi pada kinerja auditor.

Penelitian ini dilakukan pada Kantor Akuntan Publik (KAP) di Provinsi Bali yang terdaftar dalam Direktori yang diterbitkan oleh Institut Akuntan Publik Indonesia (IAPI) pada tahun 2017 yang seluruhnya berlokasi di Kota Denpasar. Objek penelitian ini adalah kinerja dari auditor khususnya mengenai profesionalisme auditor, komitmen organisasi dan etika profesi yang bekerja di Kantor Akuntan Publik (KAP) di Provinsi Bali yang terdaftar dalam Direktori yang diterbitkan oleh Institut Akuntan Publik Indonesia (IAPI) pada tahun 2017. Variabel terikat atau variabel dependen dalam penelitian ini yang menjadi variabel terikat dalam penelitian ini adalah kinerja audit (Y). Variabel bebas atau variabel independen dalam penelitian ini adalah profesionalisme auditor $\left(\mathrm{X}_{1}\right)$, komitmen organisasi $\left(\mathrm{X}_{2}\right)$, dan etika profesi $\left(\mathrm{X}_{3}\right)$.

Pada penelitian ini menggunakan data kuantitatif dan kualitatif. Data kualitatif yang digunakan dalam penelitian ini adalah nama dan alamat Kantor Akuntan Publik yang terdaftar di Institut Akuntan Publik Indonesia. Sedangkan data kuantitatif yang digunakan dalam penelitian ini adalah jumlah auditor yang bekerja di Kantor Akuntan Publik yang terdaftar di Institut Akuntan Publik Indonesia dan hasil kuesioner yang berupa jawaban responden yang diukur dengan skala Likert tentang variabel yang dimaksud yaitu pengaruh profesionalisme auditor, komitmen organisasi dan etika profesi pada kinerja auditor Kantor Akuntan Publik di Provinsi Bali. 
Penelitian ini dalam pengolahan data menggunakan data primer dan data sekunder. Data primer dalam penelitian ini adalah hasil pengisian kuesioner oleh responden seputar variabel yang dimaksud yaitu pengaruh profesionalisme auditor, komitmen organisasi dan etika profesi pada kinerja auditor Kantor Akuntan Publik di Provinsi Bali. Data sekunder pada penelitian ini adalah daftar nama Kantor Akuntan Publik di Bali yang menjadi anggota Institut Akuntan Publik Indonesia. Populasi dalam penelitian ini adalah seluruh auditor yang bekerja pada Kantor Akuntan Publik di Provinsi Bali. Kantor Akuntan Publik yang digunakan adalah Kantor Akuntan Publik yang terdaftar dalam Direktori yang diterbitkan oleh Institut Akuntan Publik Indonesia tahun 2017 yang beralokasi di Bali sejumlah 7 Kantor Akuntan Publik. Jumlah keseluruhan auditor dari 7 kantor tersebut terdapat 65 orang auditor.

Metode penentuan sampel yang digunakan dalam penelitian ini adalah metode purposive sampling. Adapun yang menjadi kriteria responden dalam penelitian ini adalah seluruh auditor yang bekerja pada KAP di Provinsi Bali yang memiliki pengalaman melaksanakan pemeriksaan audit minimal 1 tahun. Kriteria ini dipilih karena auditor yang memiliki pengalaman melaksanakan pemeriksaan audit minimal 1 tahun memilki waktu dan pengalaman untuk beradaptasi serta menilai kondisi lingkungan kerja (Wibowo, 2009). Setelah menggunakan teknik purposive sampling, didapatkan sampel sebanyak 65 auditor dari jumlah populasi sebanyak 65 auditor. Rincian nama KAP, jumlah auditor pada masing-masing kantor akuntan publik dan jumlah auditor yang memenuhi syarat menjadi sampel dapat dilihat pada tabel 1 . 
Tabel 1.

Jumlah Auditor Kantor Akuntan Publik

\begin{tabular}{|c|c|c|c|}
\hline No. & $\begin{array}{c}\text { Nama Kantor Akuntan } \\
\text { Publik }\end{array}$ & $\begin{array}{l}\text { Jumlah Auditor } \\
\text { (Orang) }\end{array}$ & $\begin{array}{c}\text { Jumlah Auditor yang } \\
\text { Memenuhi Kriteria }\end{array}$ \\
\hline 1 & KAP I Wayan Ramantha & 9 & 9 \\
\hline 2 & $\begin{array}{l}\text { KAP Johan Malonda } \\
\text { Mustika \& Rekan (Cabang) }\end{array}$ & 12 & 12 \\
\hline 3 & KAP K. Gunarsa & 3 & 3 \\
\hline 4 & $\begin{array}{l}\text { KAP Drs. Ketut Budiartha, } \\
\text { MSi }\end{array}$ & 10 & 10 \\
\hline 5 & $\begin{array}{l}\text { KAP DRS. Ketut Muliartha } \\
\text { RM \& Rekan }\end{array}$ & 7 & 7 \\
\hline 6 & $\begin{array}{l}\text { KAP Drs. Sri Marmo } \\
\text { Djogosarkoro \& Rekan }\end{array}$ & 19 & 19 \\
\hline 7 & $\begin{array}{l}\text { KAP Drs. Wayan } \\
\text { Sunasyana }\end{array}$ & 5 & 5 \\
\hline & Total & 65 & 65 \\
\hline
\end{tabular}

Sumber : Data Diolah, 2017

Metode pengumpulan data yang digunakan dalam penelitian ini yaitu dengan menggunakan kuesioner. Dalam penelitian ini penulis terjun langsung ke lokasi penelitian dan memberikan kuesioner secara langsung kepada responden untuk dapat diisi. Data yang diperoleh dari metode ini adalah hasil pengisian kuesioner oleh responden seputar variabel yang akan diteliti yaitu profesionalisme auditor, komitmen organisasi dan etika profesi pada kinerja auditor oleh auditor Kantor Akuntan Publik (KAP) di Provinsi Bali. Pengisisan kuisioner menggunakan skala likert 1 sampai 5.

Teknik analisis data yang digunakan didalam penelitian ini dilakukan dengan menggunakan analisis regresi linear berganda. Analisis regresi linear berganda digunakan untuk mengetahui atau memperoleh gambaran mengenai pengaruh profesionalisme auditor $\left(\mathrm{X}_{1}\right)$, komitmen organisasi $\left(\mathrm{X}_{2}\right)$ dan etika profesi $\left(\mathrm{X}_{3)}\right.$ pada kinerja auditor $(\mathrm{Y})$. Analisis ini dilakukan dengan bantuan program SPSS (Statistic Package of Social Science) For Windows. Model regresi 
linier berganda yang digunakan dalam penelitian ini di tunjukkan oleh persamaan sebagai berikut.

$Y=\alpha+\beta_{1} X_{1}+\beta_{2} X_{2}+\beta_{3} X_{3}+e$

Keterangan:

$\mathrm{Y} \quad=$ kinerja auditor

$\alpha \quad=$ konstanta

$\beta_{1} \quad=$ koefisien regresi profesionalisme auditor

$\beta_{2} \quad=$ koefisien regresi komitmen organisasi

$\beta_{3} \quad=$ koefisien regresi etikaprofesi

$\mathrm{X}_{1} \quad=$ profesionalisme auditor

$\mathrm{X}_{2}=$ komitmen organisasi

$\mathrm{X}_{3}=$ etika profesi

$\mathrm{e} \quad=$ tingkat kesalahan atau tingkat gangguan

\section{HASIL DAN PEMBAHASAN}

Penelitian ini dilakukan untuk meneliti mengenai pengaruh profesionalisme auditor, komitmen organisasi, dan etika profesi pada kinerja auditor kantor akuntan publik di Provinsi Bali. Data tersebut dikumpulkan dengan cara menyebarkan kuesioner ke sembilan Kantor Akuntan Publik yang tergabung di dalam Institut Akuntan Publik Indonesia wilayah Bali. Kuesioner disebarkan sebanyak 65 kuesioner dan hanya 36 kuesioner yang kembali. Hal ini dikarenakan terdapat dua Kantor Akuntan Publik yang sudah tidak beroperasi yaitu KAP Drs. Ida Bagus Djagera dan KAP Rama Wendra dan satu Kantor Akuntan Publik tidak menerima kuesioner sejumlah auditornya yaitu KAP Drs. Sri Marmo Djogosarkoro. Dari 65 kuesioner yang dikirim maka dapat dirinci sebagai berikut pada Tabel 2. 
Tabel 2.

Daftar Penyebaran dan Pengembalian Kuesioner

\begin{tabular}{clcc}
\hline No. & \multicolumn{1}{c}{ Nama Kantor Akuntan Publik } & $\begin{array}{c}\text { Kuesioner } \\
\text { Disebar }\end{array}$ & $\begin{array}{c}\text { Kuesioner } \\
\text { Kembali }\end{array}$ \\
\hline $\mathbf{1}$ & KAP I Wayan Ramantha & 9 & 8 \\
$\mathbf{2}$ & $\begin{array}{l}\text { KAP Johan Malonda Mustika \& Rekan } \\
\text { (Cabang) }\end{array}$ & 12 & 9 \\
$\mathbf{3}$ & KAP K. Gunarsa & 3 & 3 \\
$\mathbf{4}$ & KAP Drs. Ketut Budiartha, MSi & 10 & 6 \\
$\mathbf{5}$ & $\begin{array}{l}\text { KAP DRS. Ketut Muliartha RM \& } \\
\text { Rekan }\end{array}$ & 7 & 6 \\
& $\begin{array}{l}\text { KAP Drs. Sri Marmo Djogosarkoro \& } \\
\text { Rekan }\end{array}$ & 19 & 0 \\
\hline $\mathbf{7}$ & KAP Drs. Wayan Sunasyana & 5 & 4 \\
\hline
\end{tabular}

Sumber : Data Diolah, 2017

Statistik deskriptif merupakan statistik yang memberikan gambar atau deskripsi suatu data yang dilihat dari besarnya nilai terendah (minimum), nilai tertinggi (maximum), nilai rata-rata (mean), dan simpangan baku (standard deviation) masing-masing variabel dengan $\mathrm{N}$ yang merupakan banyaknya responden dalam penelitian. Hasil analisis statistik deskriptif dapat dilihat pada Tabel 3.

Tabel 3.

Hasil Statistik Deskriptif

\begin{tabular}{lccccc}
\hline & N & Min. & Maks. & Mean & Std. Deviation \\
\hline Profesionalisme Auditor & 36 & 5 & 19,7 & 14,13 & 4,43736 \\
Komitmen Organisasi & 36 & 7,56 & 23 & 17,8 & 5,26695 \\
Etika profesi & 36 & 6,45 & 19 & 14,89 & 4,42696 \\
Kinerja auditor & 36 & 10,32 & 28,74 & 20,37 & 5,78878 \\
Valid N (Listwise) & 36 & & & & \\
\hline
\end{tabular}

Sumber: Data Diolah, 2017

Berdasarkan hasil statistik deskriptif, variabel Profesionalisme Auditor $\left(\mathrm{X}_{1}\right)$ memiliki nilai minimum sebesar 5,00, nilai maksimum sebesar 19,70, rata-rata 
(mean) sebesar 14,1331 dan standar deviasi sebesar 4,43736. Hal ini berarti terjadi perbedaan nilai profesionalisme auditor yang diteliti terhadap nilai rata-rata sebesar 4,43736.

Variabel Komitmen Organisasi $\left(\mathrm{X}_{2}\right)$ memiliki nilai minimum sebesar 7,56, nilai maksimum sebesar 23,00, rata-rata (mean) sebesar 17,7975 dan standar deviasi sebesar 5,26695. Hal ini berarti terjadi perbedaan nilai komitmen organisasi yang diteliti terhadap nilai rata-rata sebesar 5,26695. Variabel Etika Profesi $\left(\mathrm{X}_{3}\right)$ memiliki nilai minimum sebesar 6,45, nilai maksimum sebesar 19,00, rata-rata (mean) sebesar 14,8894 dan standar deviasi sebesar 4,42696. Hal ini berarti terjadi perbedaan nilai etika profesi yang diteliti terhadap nilai rata-rata sebesar 4,42696.

Analisis linear berganda ini digunakan untuk mengetahui besarnya pengaruh Profesionalisme Auditor $\left(\mathrm{X}_{1}\right)$, Komitmen Organisasi $\left(\mathrm{X}_{2}\right)$ dan Etika Profesi $\left(\mathrm{X}_{3}\right)$ pada Kinerja Auditor (Y) Kantor Akuntan Publik di Provinsi Bali. Hasil olahan data dengan bantuan SPSS menggunakan model analisis regresi linier berganda dapat dilihat pada Tabel 4.

Tabel 4.

Hasil Analisis Regresi Linear Berganda

\begin{tabular}{lccc}
\hline \multirow{2}{*}{ Variabel } & \multicolumn{2}{c}{ Unstandardized Coefficients } & $\begin{array}{c}\text { Standardized } \\
\text { Coefficients }\end{array}$ \\
\cline { 2 - 4 } & B & Std. Error & Beta \\
\hline Constant & 0,256 & 2,625 & \\
Profesionalisme auditor & 0,412 & 0,148 & 0,316 \\
Komitmen organisasi & 0,447 & 0,139 & 0,407 \\
Etika profesi & 0,425 & 0,155 & 0,325 \\
\hline
\end{tabular}

Sumber: Data Diolah, 2017

$Y=0,256+0,412 X_{1}+0,447 X_{2}+0,425 X_{3}+e$ 
Nilai konstanta $(\alpha)$ sebesar 0,256 menunjukkan bahwa apabila seluruh variabel bebas bernilai nol, maka nilai dari variabel terikat sebesar 0,256 , ini berarti apabila profesionalisme auditor, komitmen organisasi, dan etika profesi tidak ada maka kinerja auditor akan buruk. Nilai koefisien regresi variabel profesionalisme auditor $\left(\beta_{1}\right)$ sebesar 0,412 artinya bila nilai profesionalisme auditor bertambah satu satuan, maka nilai dari kinerja auditor akan mengalami peningkatan sebesar 0,412 satuan dengan asumsi variabel bebas lainnya konstan.

Nilai koefisien regresi variabel komitmen organisasi $\left(\beta_{2}\right)$ sebesar 0,447 artinya bila nilai komitmen organisasi bertambah satu satuan, maka nilai dari kinerja auditor akan mengalami peningkatan sebesar 0,447 satuan dengan asumsi variable bebas lainnya konstan. Nilai koefisien regresi variabel etika profesi $\left(\beta_{3}\right)$ sebesar 0,425 artinya bila nilai etika profesi bertambah satu satuan, maka nilai dari kinerja auditor akan mengalami peningkatan sebesar 0,425 satuan dengan asumsi variable bebas lainnya konstan. Koefisien determinasi dilakukan untuk mengukur seberapa jauh variabel bebas mampu menjelaskan perubahan variabel terikatnya. Pada penelitian ini, koefisien determinasi dilihat melalui nilai Adjusted $R$ Square. Tabel 5 menunjukkan hasil uji koefisien determinasi.

\section{Tabel 5.}

\section{Hasil Uji Koefisien Determinasi $\left(\mathbf{R}^{2}\right)$}

\begin{tabular}{cccc}
\hline Model & R & R Square & Std. Error of the Estimate \\
\hline 1 & 0,814 & 0,663 & 3,51346 \\
\hline
\end{tabular}

Sumber : Data Diolah, 2017

Tabel 3 menunjukkan bahwa nilai Adjusted $R$ Square adalah sebesar 0,814.

Ini berarti kinerja auditor dapat dijelaskan oleh variabel profesionalisme auditor, 
komitmen organisasi, dan etika profesi sebesar 63,2 persen, sedangkan sisanya 36,8 persen dijelaskan oleh faktor lain yang tidak dimasukkan dalam penelitian ini.

Uji kesesuaian model (uji F) bertujuan untuk mengetahui apakah dalam penelitian ini model yang digunakan layak untuk digunakan atau tidak sebagai alat analisis untuk menguji pengaruh variabel bebas pada variabel terikatnya. Untuk mengetahui hasil uji F dapat dilakukan dengan membandingkan tingkat signifikansi masing-masing variable bebas dengan nilai 0,05. Apabila tingkat signifikan lebih kecil dari 0,05 atau 5 persen maka hubungan antar variabel bebas adalah signifikan mempengaruhi variabel terikat yaitu kinerja auditor.

Tabel 6.

Hasil Uji Kelayakan Model (Uji F)

\begin{tabular}{ccc}
\hline Model & F & Sig. \\
\hline Regression & 21,003 & 0 \\
\hline
\end{tabular}

Sumber : Data Diolah, 2017

Berdasarkan hasil pengujian disajikan dalam Tabel 6 dapat dilihat bahwa nilai signifikan uji $\mathrm{F}$ adalah sebesar 0,000 yang menunjukkan lebih kecil dari 0,005. Hal ini berarti variabel profesionalisme auditor, komitmen organisasi, dan etika profesi berpengaruh secara serempak variabel terikatnya yaitu kinerja auditor.

Uji statistik $\mathrm{t}$ bertujuan untuk menunjukkan seberapa jauh pengaruh satu variabel bebas secara individual dalam menerangkan variabel terikat. Level of significant yang digunakan adalah 0,05 atau 5 persen. Apabila tingkat signifikansi t lebih kecil dari 0,05 maka $\mathrm{H}_{0}$ ditolak dan $\mathrm{H}_{1}$ diterima. Hasil uji t pada penelitian ini dapat dilihat pada Tabel 7. 
Tabel 7.

Hasil Uji t

\begin{tabular}{lccc}
\hline & Model & t & Sig. \\
\hline (Constant) & 0,097 & 0,923 \\
Profesionalisme auditor & 2,794 & 0,009 \\
Komitmen organisasi & 3,21 & 0,003 \\
Etika profesi & 2,736 & 0,01 \\
\hline Sumber $:$ Data Diolah, 2017 & &
\end{tabular}

Sumber : Data Diolah, 2017

Berdasarkan Tabel 7 dapat dilihat bahwa nilai signifikasi uji t untuk variable profesionalisme auditor sebesar 0,009 maka tingkat signifikasi $\mathrm{t}$ adalah 0,009 lebih kecil dari 0,05 . Hal ini menunjukkan bahwa hipotesis 1 yang menyatakan profesionalisme auditor berpengaruh positif pada kinerja auditor diterima $\left(\mathrm{H}_{1}\right.$ diterima).

Hasil penelitian menunjukkan adanya hubungan antara profesionalisme auditor dengan kinerja auditor. Semakin tinggi tingkat keprofesionalismean auditor maka kinerja yang dihasilkan akan semakin memuaskan. Profesional sering dinyatakan dalam literatur, profesionalisme berarti bahwa orang bekerja secara profesional. Profesionalisme berarti bahwa auditor wajib melaksanakan tugas-tugasnya dengan kesungguhan dan kecermatan, sebagai seorang yang professional, auditor harus menghindari kelalaian dan ketidakjujuran. Jadi dapat disimpulkan apabila seorang auditor tidak memiliki atau telah kehilangan sikap profesionalismenya sebagai seorang auditor maka sudah dapat diyakini bahwa auditor tersebut tidak akan dapat menghasilkan hasil kinerja yang memuaskan dan dengan baik, maka dengan begitu kepercayaan dari masyarakat akan hilang begitu saja terhadap auditor tersebut. Oleh sebab itu sangatlah diperlukan sikap profesionalisme tersebut dalam menyelesaikan tugas - tugas dengan tepat waktu. Hasil penelitian ini didukung oleh penelitian Bamber (2002), Cohen (2001), 
Pawitra (2011) yang menunjukkan bahwa profesionalisme berpengaruh positif terhadap kinerja auditor.

Berdasarkan Tabel 7 dapat dilihat bahwa nilai signifikasi uji t untuk variabel komitmen organisasi sebesar 0,003 maka tingkat signifikasi t adalah 0,003 lebih kecil dari 0,05 . Hal ini menunjukkan bahwa hipotesis 2 yang menyatakan komitmen organisasi berpengaruh positif pada kinerja auditor diterima $\left(\mathrm{H}_{2}\right.$ diterima).

Hasil penelitian menunjukkan adanya hubungan antara komitmen organisasi dengan kinerja auditor. Seorang auditor yang memiliki komitmen yang tinggi terhadap organisasi dimana dia bekerja, akan timbul rasa memiliki terhadap organisasinya tersebut. Seorang auditor harus memiliki loyalitas yang tinggi dan rasa kesetiaan terhadap organisasinya, sehingga akan mendorong auditor untuk bekerja dengan sungguh-sungguh demi menghasilkan pemeriksaan audit yang berkualitas. Auditor akan merasa senang dalam bekerja dan akan berusaha bekerja sebaik mungkin untuk organisasinya yang akan berdampak pada peningkatan kinerja. Hasil penelitian ini didukung dengan hasil penelitian yang dilakukan oleh Fernando et al. (2005) dan Yuskar dan Selly Devisia (2011) yang menyatakan bahwa komitmen organisasi berpengaruh pada kinerja auditor.

Berdasarkan Tabel 7 dapat dilihat bahwa nilai signifikasi uji t untuk variabel etika profesi sebesar 0,010 maka tingkat signifikasi t adalah 0,010 lebih kecil dari 0,05. Hal ini menunjukkan bahwa hipotesis 3 yang menyatakan pelatihan profesi berpengaruh positif pada kinerja auditor diterima ( $\mathrm{H}_{3}$ diterima). 
Hasil penelitian menunjukkan adanya hubungan antara etika profesi dengan kinerja auditor. Apabila seorang auditor tidak memiliki atau mematuhi etika profesinya maka ia tidak akan dapat menghasilkan kinerja yang memuaskan bagi dirinya sendiri maupun kliennya. Oleh sebab itu seorang auditor haruslah memegang teguh etika profesinya sebagai seorang auditor agar tidak menyalah gunakan profesinya sendiri. Maka dari itu etika profesi berpengaruh positif pada kinerja auditor. Hasil penelitian ini didukung dengan hasil penelitian yang dilakukan oleh Putri \& Suputra (2013) menunjukkan bahwa etika profesi berpengaruh positif terhadap kinerja auditor.

\section{SIMPULAN}

Berdasarkan hasil analisis yang diperolah dalam penelitian ini, maka dapat disimpulkan Profesionalisme auditor berpengaruh positif pada kinerja auditor. Hal ini menunjukkan bahwa semakin professional seorang auditor tersebut maka kinerja dari seorang auditor tersebut akan semakin baik. Komitmen organisasi berpengaruh positif pada kinerja auditor. Hal ini menunjukkan bahwa semakin tinggi komitmen seorang auditor pada suatu kantor akuntan publik maka akan semakin baik kinerjanya. Etika profesi berpengaruh positif pada kinerja auditor. Hal ini menunjukkan bahwa semakin auditor tersebut mematuhi etika profesi yang berlaku maka kinerja auditor akan meningkat.

Adapun saran yang diberikan untuk penelitian yang akan datang Bagi auditor agar tetap menerapkan profesionalisme auditor, komitmen organisasi, dan etika profesi dalam menjalankan pekerjaan terutama yang berhubungan dengan keterlibatan kerja yang tinggi pada kantor akuntan publik. Penelitian selanjutnya 
sebaiknya menambah cakupan sampel penelitian, baik dengan memperluas wilayah, maupun jenis auditor, yaitu auditor internal dari perusahaan swasta atau instasi pemerintahan. Bagi peneliti selanjutnya disarankan untuk menambah variabel independen, guna mengetahui variabel-variabel lain yang dapat mempengaruhi dan memperkuat atau memperlemah variabel dependen.

\section{REFERENSI}

Abu Nazarudin. 2013. Pengaruh Etika, Pengalaman Audit, dan Independensi Terhadap Skeptisisme Professional Auditor Badan Pemeriksa Keuangan Republik Indonesia Perwakilan Provinsi Kepulauan Bangka Belitung. Jurnal Akuntansi \& Keuangan, 6(1): h:1-13.s

Achmat, Zakarija. 2010. Theory of Planned Behavior, Masihkan Relevan?. http://zakarija.staff.umm.ac.id/files/2010/12/, diakses tanggal 14 Mei 2017.

Ajzen, Icek. 1991. Organizational Behavior and Human Decison Process : Theory of Planned Behavior Online's. http://home.comcast.net/-ajzen/tpb.obhdp295, diakses tanggal 14 Mei 2017.

Ariani. 2009. Pengaruh Profesionalisme, Etika Profesi, Tingkat Pendidikan dan Pengalaman Kerja Inspektorat Provinsi Bali. Skripsi Fakultas Ekonomi Universitas Udayana.

Ariyanto, Dodik dan Ardani Mutia Jati. 2010. Pengaruh Independensi, Kompetensi, dan Sensitivitas Etika Profesi Terhadap Produktivitas Kerja Auditor Eksternal (Studi Kasus Pada Auditor Perwakilan BPK RI Provinsi Bali). Jurnal Akuntansi dan BisnisVolume 5 (2).h:157-168.

Baihaqi, Muhammad Fauzan. 2010. Pengaruh Gaya Kepemimpinan Terhadap Kepuasan Kerja dan Kinerja dengan Komitmen Organisasi Sebagai Variabel Intervening (Studi Pada PT. Yudhistira Ghalia Indonesia Area Yogyakarta). Skripsi. Semarang: Universitas Diponegoro.

Bamber, E Michael dan Iyer, Venkataraman M.2002. Big 5 auditors' professional and organizational identification: Consistency or conflict. A Journal Practice \& Theory Volume 20 (2).h:21.

Bariyima David Kiabel, 2012. Auditor Internaling and Performance of Government Enterprises: A Nigeria Study. Double Blind Peer Reviewed International Research Journal, 12 (6) : 1-17. 
Cohen, Jeffrey R danSingle Louise E.2001.An Examination Of The Perceived Impact Of Flexible Work Arrangements Professional Opportunities In Public Accounting.Journal of Business Ethics volume 32(4).h: 317.

Curtis, Mary B., Teresa L. Conover, Lawrence C. Chui.2012. A Cross-Cultural Study of the Influence of Country of Origin, Justice, Power Distance, and Gender on Ethical Decision.

Danielle E. Warren dan Miguel Alzola. 2008. Ensuring Independent Auditors: Increasing the Saliency of the Professional Identity. Journal. Group Decis Negot (2009) 18:41-56

Dian, Agustia. 2011. The Influence of Auditor's Professionalism to Turnover Intentions an Empirical Study on Accounting Firm in Java and Bali. Journal of Economics and Engineering. ISSN: 2078-0346. Vol 2, No 1. February. Surabaya.

Friska, Novanda.2012.Pengaruh Profesionalisme Auditor, Etika Profesi Dan pengalaman Auditor Terhadap Pertimbangan Tingkat Materialitas. Skripsi Fakultas Ekonomi Universitas Negeri Yogyakarta.

Gibson James. L, Ivancevich John M. dan Donnely James H, Jr. 1996. Organisasi Perilaku, Struktur dan Proses. Terjemahan. Jilid 1. Penerbit Binarupa Aksara, Jakarta.

Gordon F. Woodbine dan Joanne Liu. 2010. Leadership Styles and the Moral Choice of Internal Auditors. Electronic Journal of Business Ethics and Organization Studies. Vol. 15 No. 1.

Hall, James A dan Tommie Singleton. (2007). Audit dan Assurance Teknologi Informasi Edisi Kedua Jakarta: Selemba Empat

Hardjana, Agus. (2002). Pekerja Profesional. Yogyakarta : Kanisius.

Hudiwinarsih, Gunasti.2010. Auditors'Experience, Competency, And Their Independency As The Influencial Factors In Professionalism.Journal of Economics, Business and Accountancy Ventura Volume 13 ( 3 ).h:253264.

Kalbers, Lawrence P. Dan Fogarty, Timothi J. 1995. "Profesionalism and Its Consequences: A Study of Internal Auditors". Auditing : A Journal of Practice adn Theory. Ohio.

Kuang Chi, et. Al. 2007. Investigating the relationship among leadership styles, emotional intelligence ang organization commitmen on job performance: A study of sales people in Thailand.Journal of human Resource and Adult learning vol 3,num.2 december 2007. 
Lekatompessy, J.E (2003), Hubungan profesionalisme dengan konsekuensinya ; komitmen organisasional, Kepuasan Kerja, Prestasi Kerja dan Keinginan Berpindah (StudiEmpiris di Lingkungan Akuntan Publik). Jurnal Bisnis dan Akuntansi. Vol.5 No.1 April 2003 Hlm. 69-84.

Making.Journal Of Internasional Accounting Research Volume 11 ( 1 ).h:534.Allen, Mary F., Linville, Mark, Stott, David M.2005.The Effect of Litigation on Independent Auditor Selection. American Journal of Business Volume20 (1).h:37.

Mangkunegara, Anwar Prabu. 2005. "Evaluaso Kinerja SDM". Refika Aditama. Bandung.

Meyer, J. P. et. al. 1989. Organizational Commitment and Job Performance: It's the Nature of the Commitment That Counts. Journal of Applied Psychology, 74: 152-156

Mowday, R. T., Porter, L. W. \& Steers, R. M. 1992. Employee-organization linkages: The Psychology of commitment, absenteeism, and turnover. New York: Academic Press.

Mulyadi. (2002). Auditing. Edisi Keenam. Penerbit Salemba Empat. Jakarta.

Nouri, Hossein and Parker, Robert J. 1996. The Effect of Organization Commitment on The Relation Betwen Budgetary Participation an Budgetary Slack, Behavioral Research in Acounting, 8 : 76-90

Pawitra, Abdillah. 2011. Analisis Pengaruh Profesionalisme dan Etika Profesi Terhadap Kinerja Auditor Badan Pemeriksa Keuangan Republik Indonesia di Jakarta. Tesis Sekolah Pascasarjana Universitas Sumatera Utara.

Putri, Kompiang Martina D \& I.D.G Dharma S. 2013. Jurnal Pengaruh Independensi, Profesionalisme, Dan Etika Profesi Terhadap Kinerja Auditor Pada Kantor Akuntan Publik Di Bali. E-Jurnal Akuntansi Universitas Udayana, Bali.

Rahmawati. 2011. Pengaruh Role Stress terhadap Kinerja Auditor dengan Emotional Quotient sebagai Variabel Moderating. Skripsi. Universitas Islam Negeri Syarif Hidayatullah.

Rhara. A.A. Istri D \& I.D.G Dharma S. 2013. Jurnal Faktor-Faktor Yang Mempengaruhi Auditor Dalam Pengambilan Keputusan Untuk Memberikan Opini Audit. E-Jurnal Akuntansi Universitas Udayana, Bali.

Sanjiwani, Putri dan Wisadha, Suparta. 2016. Pengaruh Locus of Control, Gaya Kepemimpinan, dan Komitmen Organisasi pada Kinerja Auditor Kantor 
Akuntan Publik. E-Jurnal Akuntansi Universitas Udayana, 14(2): h:920947.

Satwika, Adhi Nugraha dan Ramantha, I Wayan. 2015. Pengaruh Profesionalisme, Etika Profesi, dan pelatihan Auditor Terhadap Kinerja Auditor pada Kantor Akuntan Publik di Bali. E-Jurnal Akuntansi Universitas Udayana, 13(3): h:916-943.

Seider, Scott.,et. Al. 2001. The Effects of Privileging Moral or Performance Character Development in Urban Adolescents. The Journal Of. Early Adolescence.

Skousen,C. J.,Smith,K.R.andWright,C.J. (2008). Detecting and Predecting Financial State ment Fraud: The Effecti veness of The Fraud Triangle and SAS 99. http://ssrn. com/abstract=1295494 pada 20 September 2015.

Soselisa, Rangga dan Mukhlasin. 2008. Pengaruh Faktor Kultur Organisasi, Manajemen, Strategik, Keuangan, dan Auditor terhadap Kecenderungan Kecurangan Akuntansi: Studi pada Perusahaan Publik di Indonesia. Simposium Nasional Akuntansi XI. Pontianak.

Wibowo, Hian Ayu Oceani. 2009. Pengaruh Independensi Auditr, Komitmen Organisasi, Gaya Kepemimpinan, dan Pemahaman Good Governance Terhadap Kinerja Auditor (Studi emiris pada Kantor Akuntan publik di Daerah Istimewa Yogyakarta). Skripsi. Fakultas Ekonomi Universitas Islam Indonesia.

Wiguna, I Made A \& I.D.G Dharma S. 2016. Jurnal Pengaruh Tindakan Supervisi, Pengalaman Kerja, Komitmen Organisasi, Dan Komitmen Profesional Terhadap Kepuasan Kerja Auditor. E-Jurnal Akuntansi Universitas Udayana, Bali. 